\title{
Civil Religion in Contemporary Japan
}

\author{
IAN READER
}

\section{Introduction: Secular Society and the Concept of Civil Religion}

Japan is a secular society in that there is a formal constitutional separation between state and religion which ensures that the state refrains from religious activities, and that religious organizations cannot receive any privileges from the state, nor exercise any political authority. ${ }^{1}$ The 1946 Constitution, which of course was promulgated by an American-dominated Occupation government and based upon American concepts of the separation of church and state, formally broke one of the most enduring themes in Japanese history, that of the close relationship between religion, politics and state, in which the state patronized and supported specific religious traditions, which in turn provided support and legitimization for the state, and which also served as a force for national unity and the development of a sense of national (and, indeed, nationalistic) consciousness. While the example of State Shinto, which had been a major ideological prop of the militant and Imperialist nationalism of the 1868-1945 period, was foremost in the minds of those who framed the 1946 Constitution, Shinto was not the only religion that has been in such a position in Japan. Indeed, Buddhism had itself been closely associated for long periods of Japanese history with the state, operating almost as a pillar of the political system from its earliest entry into Japanese society, through to its role as a virtual system of local government and control during the Tokugawa period. Through much of Japanese history, then, a civil religion (to use Rousseau's term brought into prominence by Robert Bellah) ${ }^{2}$ existed framed around a specific religious tradition, most recently State Shinto, and closely associated with the public and political realms.

In the current situation, however, through the rupture of the bonds that tied religion and state, there is no longer any overarching or dominant religion in Japan privileged by its association with, or patronage of, the state. Religion is no longer a public matter but has 
been confined to the private sphere. Whilst there is still widespread popular participation in the socially-oriented rituals and practices of the established religions of Shinto and Buddhism, social change, allied to the constitutional guarantee of religious freedom, along with the increasingly consumer-oriented nature of Japanese society, has stimulated immense growth in the scope of religious choice, which in and of itself acts as a strong bulwark against the possibility of any religion attaining a position of dominance or privilege in the future. ${ }^{3}$ The legal separation of religion and state, the processes of religious privatization and the multiplicity of competing religious movements and choices, however, do not necessarily mean the non-existence of core religious values or meanings common to a large majority of people; nor do they mean that religion can no longer play a part in framing the self-awareness or identity of a society and its people. As various scholars such as Byron Earhart ${ }^{4}$ and myself ${ }^{5}$ have shown, there is a general core of commonly held assumptions, beliefs, practices, customs, attitudes and expectations that still (even in a society which is itself undergoing rapid change) continue to provide a sense of unity and cultural belonging to the large majority of Japanese people, and to contribute to the construction and affirmation of Japanese identity, even in the absence, nowadays, of the former association between religion and state. ${ }^{6}$

To some extent this notion of a shared religion which, whilst it is not of any one particular tradition, extends across a society and culture even where a formal separation of religion and state exists, is similar to that articulated by Robert Bellah in his famous essay on civil religion in America. ${ }^{7}$ In that essay Bellah sought to demonstrate that the separation of religion and state, and the lack of any one dominant or privileged religion, does not mean that the society concerned has no set of core religious values. Bellah argued that societies, even where there are legal bonds that separate state and religion, and prevent the emergence of a dominant religious form that, through union with the state, serves to provide a sense of identity and to act as a unifying force within society, may nonetheless have, or develop, a form of religion widely shared by the vast majority of the members of that society, and that helps affirm common belongings and a sense of national identity. This religion, which Bellah, following Rousseau, termed civil religion, is not predicated upon specific personal commitment in terms of beliefs and doctrines, but 
rather reflects a shared social, cultural and religious sense of identity and belonging.

Bellah's discussion of civil religion expresses the view that "the separation of church and state has not denied the political realm a religious dimension," ${ }^{\prime 8}$ and he draws attention to the ways in which politicians such as President Kennedy have made use of religious terminology within a non-denominational framework, to emphasize symbols and values apparently common to and shared by American people in general. While Bellah focused primarily on such values, symbols and images, he also drew some attention to public rituals and calendrical events such as Memorial Day, which he suggested constituted an "annual ritual calendar for civil religion." ${ }^{9}$ To Bellah this American civil religion of symbols, values, images and events is made up of "certain common elements of religious orientation that the great majority of Americans share ... [that] provide a religious dimension for the whole fabric of American life," a genuine vehicle of national religious self-understanding."11

It should be noted that (although Bellah does not specifically emphasize this point) civil religion per se has no organization or sustained structure, certainly none ordained by any particular authority; hence it could be open to various patterns of interpretation or use by different groups. Bellah's discussion primarily draws attention to the politicized aspects of civil religion, and argues that it provides a link between the citizen and the state, a function that has been of little real contention in a society such as the USA where "the relation between religion and politics ... has been singularly smooth." ${ }^{12} \mathrm{How}^{-}$ ever, civil religion is not limited to the sphere of the relationship of citizen and state, but extends further to being "a point of articulation between the profoundest commitments of the Western religious and philosophical tradition and the common beliefs of ordinary Americans." 13

Bellah's essay stimulated general discussion about the nature (or, indeed, the very existence) of civil religion in the USA and elsewhere. One element in these discussions has been whether a civil religion of shared assumptions and values made it primarily a religion of the masses rather than the elite (and, indeed, whether it might not, as a whole, be a construct used by the elite so as to control and manipulate the masses). Karel Dobbelaere (whose article provides a good outline of some of the general theories and discussions of scholars concerned with civil religion) draws attention to sociological 
research that demonstrates that those with the highest levels of education score least well in affirmations to a commitment to elements of civil religion, and states that "it seems then that civil religion rests on the masses rather than on the elite and those in potential power positions." ${ }^{\text {14 }}$

Whether a religion of the masses or not (and, as my preliminary comments on the shared aspects of Japanese religion, above, have implied, I think that civil religion such as it is in Japan is nothing if not a shared, popular - i.e. of the people - religion), discussions have also questioned how far civil religions continue to operate in what are increasingly fragmented modern societies. Bellah himself, less than a decade after his first article, commenting on what he saw as the growth of self-interest and the increasing fragmentation of American society and the alienation of many sectors of society, appeared to come to the view that civil religion was no longer able to provide the unity and sense of shared belongings he had earlier discussed, and called American civil religion a "broken and empty shell." ${ }^{15}$

Other scholars have further questioned whether the processes of socialization that have brought about the secularization of modern societies might have themselves served to secularize and thereby emasculate civil religion. Karel Dobbelaere, for example, argued that the increasing differentiations within modern industrial societies have made the processes of social integration increasingly complex and indeed problematic; civil religion thus has less influence in providing a core of integration and identity to such societies and is hence in some decay. ${ }^{16}$

Having questioned whether civil religion was in the process of decaying or disintegrating in modern societies, however, Dobbelaere appended an interesting postscript in which he suggested that civil religion continued to operate in Japan, although he also wondered whether it might, too, in time fragment and disintegrate. I shall shortly comment on what Dobbelaere saw this "civil religion" as being, but first I should note that he is by no means alone in affirming the existence of a civil religion in Japan. Indeed, whilst scholars concerned with American civil religion seem to frame their discussions around whether it is broken and in decline, various postwar and contemporary studies of religion in (secular) Japanese society have drawn on the concept of civil religion to draw attention to shared cultural and religious values as well as religious and cultural sym- 
bols, rituals and practices, that help frame Japanese identity and consciousness (or that have been utilized for that purpose), and to thereby argue that a civil religion in some form or other exists in contemporary Japan.

Certainly there is much in Bellah's discussion that is, as I have already suggested, pertinent to discussions of religion in Japan, especially in terms of the general frameworks of shared religious assumptions that continue to provide a sense of unity and cultural identity to the large majority of Japanese people, and that provide (to paraphrase Bellah) a point of articulation between the profound commitments of Japanese religious traditions and the common beliefs and, it is important to stress, the customs and practices of ordinary Japanese people. While this civil religion may not be as closely concerned with the political realm as in the USA (since Japan has not, since the war at least, experienced the smooth relationship between religion and politics that Bellah sees in the USA), it remains concerned with national images. Even though Japan is now a de facto secular society, it is, I would argue, possible to discern a common, shared, civil religion in Japan. It is the intention of this current essay to first discuss some of the theories and ideas that have been discussed in recent years over what, if anything, such a Japanese civil religion might consist of, and then to outline what I see as its component parts.

\section{Theories of Civil Religion in Postwar Japan}

The strong bonds in prewar Japan between Shinto and the state, and the close associations between Shinto and aspects of Japanese nationalism have made Shinto an obvious focus of many discussions on civil religion in Japan. Some commentators, wary perhaps of the reemergence of a union between Shinto and the state, have discerned in postwar Shinto and in the attempts that have been made by interested parties to revise its status or to reinstate some of its prewar privileges, the seeds of an emergent civil religion. K. Peter Takayama, for example, has drawn attention to what he sees as a resurgence of Japanese nationalistic religious sentiments, which he identifies especially with the Yasukuni shrine, the Shinto shrine for deceased soldiers that was supported by the state as a national shrine in the prewar era, and the periodic attempts made (generally 
by those on the political right) to restore its former status as a state-funded shrine and national memorial to the dead. ${ }^{17}$ In these moves, and in the attempts he perceives as being made to link religious feeling to such national symbols, and particularly to Shinto, Takayama suggests that there is an attempt to revitalize Japanese civil religion. It is a revitalization because, in his eyes, it involves restoring (albeit in a less oppressive form) Shinto to the sort of position it occupied prior to 1945, as the predominant focus of Japanese religious identity. This revitalization, he sees, is "the effort to restore something sacred out of the past, spurred by a sense of decadence in the present." ${ }^{18}$ Since Shinto, according to Takayama, is considered by many Japanese to be not so much a private (i.e. personal) religion as a public (i.e. community-centered) one, it can be utilized, adopted (and presumably, one would add, manipulated), for civil purposes. Takayama considers that the Yasukuni issue is but one of a number of interrelated ones (including attempts to reform the education agenda to place more focus on the glories of Japanese history and to thereby infuse a greater sense of patriotism amongst the young) concerned with restating nationalist agendas and with rearticulating a sense of national strength and pride.

Takayama appears, therefore, to be suggesting that attempts are being made to restore Shinto to the form of status, if perhaps in a less extreme manner, that it previously had as supporter and legitimator of the state and as the dominant medium for the expression of Japanese identity and social cohesion. There are aspects of his thesis that I find pertinent to discussions of civil religion in Japan, particularly the notion of restoring something sacred from the past - or to be more accurate, of attributing the past, and the notion of tradition, with special and almost sacred qualities. This extends beyond the limited spheres of Shinto nationalism, however, to the amorphous yet strong trend in contemporary Japanese social, cultural and religious life towards the idealization of traditional Japanese culture and landscape, and of the Japanese past. This is found in the nostalgicized images of traditional Japan used in numerous forms of popular literature and advertisements produced by such diverse groups as political parties, Buddhist sects, tourist boards and food vendors. ${ }^{19}$ It is especially prevalent in such emotionally-laden terms and concepts as furusato, a term literally meaning "one's native village," which is suggestive of a Japanese landscape and community steeped in Japanese cultural traditions and unsullied by external, modernizing and 
westernizing influences. ${ }^{20}$ The attempts made by the (then) ruling Liberal Democratic Party (LDP) from the 1970s onwards to promote rural regeneration and to strengthen the social, cultural, and economic fabric of the country at local levels through their furusatozukuri ("building a new furusato") movement and policies are some of the more public aspects of this wider trend. ${ }^{21}$

While Takayama is correct in drawing attention to the ways in which the past has become idealized and valorized in Japan, the main problem with his thesis is that he relates it to Shinto alone, and in particular to Shintoesque religious nationalism centered on such symbols as the Yasukuni shrine. This, it seems to me, allows the concept of civil religion to be too readily trapped by the ghosts of the past. Certainly prewar Shinto provided a form of civil religion which focused on a number of symbols (e.g. the Emperor, Yasukuni shrine, etc.) and imbued them with religious significance for the Japanese nation as a whole. However, to assume that, because Shinto formed the basis of prewar civil religion, any modern form of civil religion has to revolve around Shinto and the symbols it utilizes is, I would argue, to misunderstand what civil religion represents and to draw its parameters too narrowly.

Certainly the uses of symbols such as the Emperor and Yasukuni could contribute to the kind of emotional sense of shared belongings and heritage that is a vital underpinning to civil religion. Yet, as the uses made of such images of cultural heritage as the furusato and of Japanese tradition show, there is ample opportunity to affirm this shared sense of emotion without recourse to such controversial and hence potentially divisive symbols as the Emperor (at least in religious contexts) or Yasukuni shrine. Moreover, while Shinto can be oriented towards expressing a form of religious nationalism, it would be wrong to think that it alone has this potential: the Buddhist sects also make use of similarly emotionally charged symbols and images of nationalism and Japanese cultural identity, as their espousal of emotionally charged terms such as the furusato, and their attacks on Western cultural values, demonstrate. ${ }^{22}$ The new religions, and especially the "new" new religions have, particularly in recent years, also expressed forms of religious nationalism that are often more vehement and expressive than anything found in contemporary Shinto rhetoric.

Perhaps more importantly, I find Takayama's perspective problematic in that the symbols he deals with (those connected to a spe- 
cific religious tradition) are in themselves contentious and contain within them not so much values shared by the large majority, but rather, the potential for division and dissent. They are perhaps too concerned with the body politic and with the state, in a society in which the relationship between religion and politics is not (unlike Bellah's view of the USA) smooth, but instead is liable to give rise to conflict and fissure. Although Takayama states that this move to revitalize Japanese civil religion rests on popular sentiment and opinion, he does not provide any clear data to underpin this statement.

It is, in fact, possible to argue that such moves rather than being based on popular support at best generate indifference. Certainly that is an impression I have gained through lengthy discussions with friends and colleagues in many walks of life in Japan, and through my observations of opinions expressed in the media and elsewhere in Japan, that probably the majority of people in Japan are either indifferent to or tired of the whole series of manipulations surrounding such questions as the Yasukuni affair, and other such constitutional wrangles. This is not to downplay the obviously strong feelings felt by many people and organizations on such issues so much as to point out that there are also many who seem relatively unconcerned in such matters.

More importantly, as Takayama himself notes, the whole series of disputes concerning the relationship of religion and the state of which Yasukuni remains one particularly charged symbol, also have generated a strong groundswell of opposition as well. Many groups and organizations from political parties to labor unions to religious movements (including new religions and movements of Buddhist and Christian persuasions) have aligned themselves against any revisions of the law. Other potential symbols of a resurgent nationalist Shinto, whether concerned with the revision of textbooks or the enthronement of an emperor, are equally contentious at these levels, and are liable to produce fissures rather than cohesion in society. This is, ultimately, why a civil religion in a society such as Japan where religion in its involvement with politics and the state has taken on oppressive aspects, cannot be based in, or revitalized through the use of, such symbols as state support for Shinto shrines or the reassertion of a politicized religious nationalism. Civil religion, if it is genuinely going to express values, assumptions and practices shared by the large majority of a society, cannot provoke widespread 
Ian Reader

dissent, conflict or fissure within that society without rapidly acquiring the status of a broken and empty shell. It is about shared, not divisive, issues and values, and since the attempts to restate the preeminence of a Yasukuni-centered Shinto nationalism do provoke genuine and heated dissent, it would be reasonable to suggest that they cannot truly form the core of contemporary civil religion.

Not all those who see a newly emergent civil religion locate it within the parameters of Shinto, however. There are some analysts such as Winston Davis who argue that if a civil religion is to exist or emerge in Japan, it will (like Japanese society itself) be secular in context, and not aligned as such to religious traditions. ${ }^{23}$ Davis, having constructed a strong case for his argument that Japan is a "relatively secular culture," 24 considers that until 1945 the Japanese "sense of identity ... rested explicitly on religious foundations;" ${ }^{25}$ until that year a civil religion formed by State Shinto and its ideology and symbols, such as the Emperor, the state and the special place of the Japanese people as expressed in Shinto nationalism, existed. The severance in law of the bond between religion and the state brought an end to this, and heralded the advent of a secular society, not just publicly and in law but also in private. The secularizing tendencies of a modern industrial society have led to increasingly secular attitudes amongst the populace.

Davis suggests that in this process civil religion also has been secularized, arguing that Nihonron, a term Davis translates as Japan Theory, the amorphous debates and discussions in Japan about national character, identity, and the nature of being Japanese, is in itself a form of emergent secularized civil religion. Such debates include but are not confined to the Nihonjinron (discussions about being Japanese) theories that have, as with Japan Theory in general, sought to prove or affirm Japanese cultural uniqueness, generally starting from the premise that Japan and the Japanese are somehow unique and special, and seeking to illustrate this through comparisons (invariably lacking in any sound analysis) with other cultures. The point of comparison, as Davis rightly notes, is not to understand other cultures but to demonstrate how different Japan is from them, and the gist of all such theory is in constructing a sense of identity and shared cultural values and attributes that mark out the Japanese from all others. Davis correctly presents all such debates as a search for national identity - which is, he notes, a form of secularized civil religion. 
The Nihonron and Nihonjinron debates certainly contribute to the contemporary construction of identity and of cultural belonging; as Davis comments, "many of the functions of the civil religion of pre-1945 Japan - the generation of national purpose, symbolic self-defense, value-consensus, etc. - are now being assumed by the symbols, values, and imagery produced by the literature of Japan theory." 26 However, I would caution against seeing Nihonron on its own as an emergent Japanese civil religion. While it is an interesting example of how a rather diverse assortment of ideas and images can create a common affirmation of the special nature of a people and culture, it remains too focused on images and symbols to possess much weight or substance as a religion in actuality. What Davis does not consider is that Japan Theory, rather than being an emergent secular civil religion, might not be a secularized theme within a broader, extant civil religion that encompasses secularized values concerning identity with shared cultural and religious values and practices that, in a more overtly religious dimension, do the same things. Davis' discussion of what constitutes civil religion is incomplete in that it concentrates on a narrow area concerned with symbols and cultural values, but fails to pay serious attention to the important role of practices, customs, and events such as festivals, yearly, calendrical and life-cycle customs and rituals that are closely connected with issues of cultural identity, and that also, as will be discussed below, provide an implicit framework of ethical values shared by the large majority of Japanese.

The discussion by Yanagawa Keiichi and Abe Yoshiya on the nature of religious activity and affiliation in Japan, whilst not specifically discussing the notion of civil religion, helps provide us with some useful frameworks of interpretation on the subject that enable us to overcome the shortcomings of the theories of civil religion so far discussed. ${ }^{27}$ Yanagawa and Abe outline two interlocking forms of religious behavior which they term "individual religiosity" and "community religiosity" in Japan. The former iș personal, and centered in faith and belief; it is not primarily conditioned by social circumstances, but through individual volition and commitment; the latter is more distinctly social in focus, concerned with the mobilization of people and resources in a community for ritual purposes, usually involving community members as representatives of groups. Participation in community events and religious rituals, they argue, demonstrates one's reliability, and hence is a way of affirming one's 
identity as a member of the community, and of demonstrating one's (and one's family/household's) commitment to the community and its values. Participation in festivals and other such events thus would appear to involve ethical commitment to the wider community of which the individual is a member. Yanagawa and Abe state that in Japan community religiosity has precedence over individual religiosity - perhaps a point that is less clearly certain in the 1990s than in the 1970s, when they wrote their article, but still, I would argue, broadly valid. A case in point from my own experience is the Japanese student I used to teach, who converted to Mormonism but who continued, as he informed me, to participate in various activities with his family, such as going to the local shrine with them at New Year and to the family grave at the o-bon festival not because he approved of such customs in religious terms but because they were customs, family events and duties.

Yanagawa and Abe's view of community religiosity as a dominant strand in Japanese religious behavior provides us with an added dimension to the theories of civil religion we have met so far, not because they explicitly posit community religiosity as civil religion, but because they indicate how important community religiosity is as a focus of action and as an expression of ethical values (which is what reliability is in community terms). These themes are to a degree developed by Karel Dobbelaere ${ }^{28}$ in his previously mentioned article. Dobbelaere ends his assessment of civil religion in general by describing Shinto as an "operative" religion ${ }^{29}$ in that it provides a "system of attitudes, beliefs, feelings, standards, and practices that provide society with an ultimate context of meaning and value, in terms of which social life is integrated and social activities are validated. ${ }^{30}$ He thus suggests somewhat tentatively that it is Japan's civil religion; by contrast he describes Buddhism as a "conventional" religion $^{31}$ in Japan, i.e. one concerned with eschatological and personal issues of faith and belief.

He affirms some of the points made by others about Shinto, that it provides a framework and set of symbols that reflect Japanese cultural identity and belonging, and states that "through its myths and rituals Shinto aligns itself with the whole range of Japanese mythology, history, tradition and aspirations. ${ }^{1{ }^{132}}$ He pays less attention to the levels of symbolism and imagery (which, as I have suggested earlier, are too thin on their own to constitute a civil religion, but which are nevertheless important elements within its construction), 
however, than to Shinto as an expression of community religiosity, which he clearly interprets as central to civil religion. Dobbelaere discusses Shinto in action through its festivals, and calendrical and life cycle visits to shrines, such as the shichigosan (7-5-3) festival in November, in which boys aged 5 and girls aged 3 and 7 are taken to the shrine to be blessed and placed under the protection of the Shinto gods, seijin no hi, the coming of age ritual for people reaching the age of majority, 20, which is celebrated in January, ${ }^{33}$ and the first shrine visit of the year, hatsumoode, during the New Year festival, all of which are examples of how people are mobilized in terms of community. He also examines Shinto's operative nature in the community by examining its role in commerce, by drawing attention to the close associations between shrines, gods, and companies, and showing how through such roles Shinto is harnessed to supporting the economic means of production. In particular he mentions the presence of shrines on the roofs of department stores, and the occurrence of company shrines and gods whose role is to "stimulate cohesion and productivity."134

Dobbelaere's thesis has much to commend it, especially in its ability to go beyond the narrow confines of symbols and images so as to focus on events and on the operative role played by Shinto within life. Where it is problematic is in its artificial division of Shinto and other Japanese religious traditions. Much of what he attributes to Shinto - the promotion of cultural values, festivals, and production, and the emphasis on community values, for example - are valued and promoted by other religious traditions as well. Buddhism, for example, especially in rural areas, has long played a role in the cohesion of communities, particularly in its support of such primary social units as the household. Its priests have also performed rituals for the well-being of society and of companies, and Buddhism has lent its moral support to the processes of production through such rites and through the promotion of ethical values designed to encourage hard work and loyalty. ${ }^{35}$ Buddhism also plays a major role in the cycle of calendrical events in Japan, and it has been associated with the promotion of Japanese cultural values, and at times of nationalist sentiment as well. Certainly Shinto aligns itself with the whole of Japanese mythology, history, tradition and aspirations, but Buddhism also has a very deep and close, indeed formative, involvement with these; indeed I along with others would argue that to separate Shinto and Buddhism in such respects, or indeed, in 
terms of operative effects and manifestations within Japanese society, is to misrepresent their often interactive roles. ${ }^{36}$

It would be fair, also, to point out that the new religions of Japan, which in broad terms share many of the assumptions and perspectives of the established religions, also display some common characteristics in these areas. Many new religions carry out festivals and calendrical rituals such as hatsumoode and shichigosan, whilst their expression of themes of Japanese cultural power and identity are an important element within their make-up and in their appeal to followers. ${ }^{37}$

What Dobbelaere attributes to Shinto alone is part of a wider, shared arena that cuts across the boundaries of any one religious tradition in Japan, but which has points in common with them all. While the issues he deals with, such as rituals, practices and social customs, are operative religious elements in Japanese culture that affirm and confirm identity and social cohesion, and hence are intrinsic aspects of civil religion, they are not limited to one religious tradition alone.

\section{Of Images, Identity, Rituals and Benefits: The Nature of Japanese Civil Religion}

What is interesting in, and common to, all the previous discussions is the view that a civil religion in some form exists or is in the process of emerging in Japan and that, despite the obvious ethnocentric tendencies within it, it is not necessarily limited directly to politics and the state. I have already made it clear that I share in the sentiments of authors such as Davis, Takayama, and Dobbelaere, in their view that a civil religion exists in Japan, and I have suggested that it contains elements that each of them has drawn attention to, although I have also suggested that their perspectives on civil religion need to be widened a little. In particular I would like to extend Dobbelaere's focus on practical and ritual events (events that are of course not restricted only to Shinto) and relate it to some of the wider issues of national image and the construction of cultural identity expounded by Davis, to suggest that a civil religion shared by most Japanese and concerned with and consisting of common concerns, practices, values, ethics, emotional constructs and orientations exists, extending beyond the boundaries of any one religion but sharing common 
ground with most active religious traditions in Japan. This civil religion is practical in purpose and is, in effect, a popular religion that expresses the common language of religion; as such it is not associated or aligned with areas of activity or image that provoke dissent and conflict.

Its role in framing identity has been widely recognized, and as Davis has shown in his discussion of Japan Theory, cultural belonging in itself is part of civil religion, providing an emotional underpinning of identity. This emotional sense of belonging is enhanced by the processes that ascribe special cultural significance to such aspects of Japan as its landscape, sacralized through the imagery of the furusato discussed earlier. The notion of the land as sacred has, of course, been a recurrent theme in Japanese religious traditions, expressed not only in Shinto myths which depict a direct relationship between the land and the Shinto gods, but in the religious traditions that consider mountains to be specially sacred, and in the folk and Buddhist traditions, whose Buddhas and Bodhisattvas and other deities frequently manifest themselves in legends to sacralize a particular location. The ways in which the furusato, which is deeply ingrained with notions of traditional belonging and of yearning for an idealized, lost past has been utilized as an image both politically and religiously, reflect a continuation, albeit often in more secular terms, of these processes of sacralizing the landscape. ${ }^{38}$ This, I have already suggested, can be related also to Takayama's notion of a revitalized civil religion which sought to "restore the sacred out of the past." Thus the emotive language used to idealize the furusato as a symbol of shared traditions, unsullied by the present (and untouched by the outside world), manifests an attempt to build a new sense of emotional community and belonging framed round a series of images of a shared past that never really existed, but which provide a strand of common identity central to Japanese civil religion.

Rhetoric and images alone, however, as has been stated earlier, do not constitute a coherent religion, not even an amorphous civil religion. Shared emotions and feelings are made real and brought into life through actions and practices. The furusato imagery would be little more than shallow rhetoric were it not used to attract people to events and activities associated with traditional religious culture, such as festivals and pilgrimages, and it is through performing such activities that participants may acquire the emotive feeling of returning to their roots, of experiencing the shared emotions of the furusato 
along with their fellows. Kurehayashi Shooji considers that a major reason for the popularity of festivals (matsuri) is that they have come to be seen as representing a "spiritual homeland" (kokoro no furusato) for the Japanese who have lost their roots in modern society. ${ }^{39}$ It is through participating in festivals, in visiting the shrines and enjoying the fun, the excitement and the frivolity of the festival, that such experiences are encountered and that the emotional values of the imagery are made real.

It is thus through practice and through concrete actions that the values of Japanese civil religion are expressed and made visible. This point is demonstrated by the symbolic meaning of the mikoshi, or portable shrine, used to transport the shrine deity around the local area, which plays a part in many festivals. The mikoshi is usually carried by young men who represent the various households within the shrine's parish. Their participation, inter alia, thus represents a form of community religiosity, expressing the participants' reliability and sense of obligations to the community. Since these portable shrines are usually cumbersome, to carry them properly involves close cooperation between the carriers, and it entails them all pulling together at the same time. The carrying of the mikoshi thus serves as a metaphor for the importance of cooperation between households (of whom the carriers are representatives) and within the community. Though such ideals, which are expressed in other parts of many festivals as well, might appear to be more pertinent to rural agricultural places which depend on communal approaches to farming, they also are reflected in many urban festivals as well, as if to emphasize the point that urban communities also require a shared sense of unity and cooperation amongst their members.

Besides being a vehicle for the overt expression of civil religious values on this level, festivals also serve as a vehicle for creating civic pride and community spirit whilst simultaneously also boosting the economic standing of the communities that run them. A good example of this is the Kobe Festival, which was established by the civic authorities in the 1971 as a means of establishing community spirit amongst the people of Kobe, a motive that appears to have been successful in that the citizens of the town and of its various wards and districts actively participate in the festival. Besides being a focus of civic pride the festival has, as intended, provided a major boost to commerce and to tourism in the city, drawing visitors from across Japan and thereby enriching the city's economy considerably, ${ }^{40}$ a 
good example of how religious themes may be utilized to stimulate economic development.

Festivals thus represent a manifestation of civil religion which fosters community spirit and encourages the economic growth of the community. The Japanese have high rates of participation not just in festivals but in numerous other calendrical rituals and events (nenjuugyooji), including those associated with the life cycles of individuals and families, that are held at shrines and temples. These serve further to provide a recognizable and socially framed structure to the cycle of change in the lives of people and communities; underpinning this is a notion, rooted in the patterns of agricultural life but still influential in urbanized industrial Japan, that there is a commonly-shared rhythm and cycle to life, to which people are aligned through the expression of seasonal rituals.

This pattern of calendrical events and rituals remains important in urban and rural areas alike and, indeed, could be seen as a unifying point between them. Tokyo dwellers who make the customary New Year visit to a shrine or temple (and who probably will be part of a massive crowd of visitors) may also watch, on the television, celebrations of the New Year festivities as they are held across the country, and can see, for instance, village dwellers in Kyushu performing (albeit without the massive crowds) similar activities. They can thus simultaneously be aware of the regional aspects of Japanese society as expressed through local variations in the festival, and of the common national threads that run through it. Such occasions as hatsumoode thus serve to affirm a sense of Japanese identity and community, reminding everyone that throughout the country people are doing much the same thing at this time, and making them feel parts of the same whole. The rites at New Year, indeed, extend beyond the shrine visit alone, to numerous activities that are more clearly secular in focus, from the commonly-performed acts of house cleaning and settling of debts before the end of the old year, to business rituals such as shigoto hajime, in which company employees make a pledge of allegiance to the firm at the start of work in the new year. Besides the role these play in affirming identity and social cohesion they, importantly, also express a sense of optimism and a wish for happiness and renewal in the coming year, and consequently help express the inner wishes of the people and the goals they hold both individually and collectively. ${ }^{41}$ 
There are numerous events of community religiosity and of calendrical rituals that the Japanese may take part in: space does not permit a detailed list here, but several have been mentioned already. They include the shichigosan festival, seasonal festivals such as setsubun in February which welcomes the coming of spring, rituals and prayers for personal protection during the yakudoshi or "unlucky year" (42 for men, 33 for women), and the various rituals concerned with memorializing the ancestors and focused on the graves of the dead, such as higan at the spring and autumnal equinoxes and o-bon in August.

Such calendrical and life-cycle rituals are, as has been discussed above, expressions of community religiosity that serve to affirm cultural and social orientation and identity. Participation is not a matter of personal belief so much as an expression of commitment to and identity with one's fellows. At the widest levels, then, taking part in ritual events such as hatsumoode is a practical means of expressing what is implied by the images of cultural unity and belonging: ritual events thus are practical manifestations and intrinsic parts of civil religion.

This brings me to a further, and to my mind, crucial dimension to civil religion in Japan. All the events and festivals mentioned focus in some respect on what might be termed practical benefits, on the amelioration of life, and on the importance of prosperity and happiness. At hatsumoode, for example, it is customary to pray for protection from bad luck and for the acquisition of good luck in the coming year, and it is common for people during their shrine visits to acquire various religious objects, talismans and lucky charms that symbolize these things. The shichigosan festival, in seeking divine protection for the children involved, aims to bring them happiness and good fortune. Agricultural festivals express the wishes of the community for a good and fruitful harvest, and, like all festivals, express the joy and celebration that are intrinsic to the living of a productive and happy life. The o-bon festival expresses the wish and hopes of the family for the well-being in the other world of their deceased and their ancestors. Since it is a common theme of Japanese views of the dead that the welfare and prosperity of the living is supported and watched over by the ancestors, and since failing to perform the correct rituals for the dead is to invite misfortune and bad luck, a further common thread to rituals and festivals for the 
dead implicitly seeks to ensure the good fortune and welfare of the living.

Seeking benefits in the present life from their gods, Buddhas and other spiritual entities is a religious activity that the vast majority of Japanese are involved in either periodically or regularly. Virtually all rituals and events concerned with community religiosity, from hatsumoode to local festivals, involve participants in making offerings and requests to the gods and Buddhas which seek their help and support in the pursuit of human goals and needs. Such benefits range from the spiritual (for example, peace of mind) to the more overtly material; they may be communal in nature and aimed at the common good, as in community agricultural festivals seeking a good harvest, centered on commercial concerns, or in company-sponsored shrine rituals that utilize the gods to stimulate and support the means of production, or familial, as with families praying together for the welfare of their household at New Year. They may also be personal and individual: students pray for success in their examinations, drivers for safety on the road, businessmen for company prosperity, young women for a happy marriage, couples for conception, for safe childbirth and for a healthy baby, and old people for longevity, for cures from illness and, when the time comes, for painless death.

Although the above appear to be largely centered around materialistic and self-serving ends, however, implicit within the process of seeking benefits are a number of themes that express ethical values and perspectives on life that are, I would argue, core issues in Japanese civil religion providing a moral framework for life and a religious underpinning to Japanese cultural aims and common values. Such prayers and the wishes they express reflect the importance of living a fruitful and happy life, which is certainly a primary focus of Shinto ritual, and which is expressed also as a core ethical value by many new religions; Tenrikyo, for example, emphasizes the ethical importance of yookigurashi, living a bright and happy life. Seeking benefits from the gods and Buddhas is an action in accord with a basic purpose to life in such terms; happiness is thus in and of itself an ethical value. Since success as a goal in life is affirmed through the support of the gods and Buddhas, this further provides powerful legitimization for the pursuit of prosperity in material terms and gives strong ethical support to the attainment of economic success at 
personal, community, company and national levels, for the common good as well for personal advancement.

Prayers for practical benefits and seeking the aid of the gods in the pursuit of human endeavors display a commitment towards the attainment of goals, not necessarily just in a personal sense but in terms of a sense of wider social responsibility. Praying for kootsuu an$z e n$, traffic safety, and acquiring the protection and support of the gods and Buddhas in this, implies and indeed requires that the petitioner should behave in a virtuous way; it involves a commitment to drive safely, to care for others, and to avoid accidents not just for one's own sake but for that of all people. Indeed, travel safety amulets and talismans hanging up in vehicles such as taxis, buses and trains can serve as a form of public policy statement by the commercial concerns that use them, aimed at reassuring the traveling public of the firms' commitment to ensuring their safety, and acting as a reminder to drivers of their social responsibilities for their passengers. ${ }^{42}$ Students who pray for educational success undertake a moral responsibility to work hard (hence repaying their parents' and teachers' hopes and wishes) and to succeed not just for themselves but for their family and community.

The moral attitudes underlying prayers for prosperity and happiness are further reinforced by the obligations incurred within them to provide something in return, both through making offerings to the gods, shrines and temples (an inherent part of the process of prayer and worship in Japan) and through the expression of gratitude to those deities afterwards. The importance of reciprocity as a social value and virtue which allows society to function smoothly and for its members to understand their relationships and obligations to their fellows is widely recognized and understood within Japanese society, and it is reaffirmed through the relationship people have with their gods and through the processes of seeking benefits. The duty to repay gratitude (ongaeshi) is a vital ethical injunction and activity in many Japanese religious traditions, such as the new religions, which stress gratitude as a moral virtue ${ }^{43}$ and established Buddhist sects such as Soto Zen, in whose cardinal text the Shushoogi an extended section is devoted to this virtue. ${ }^{44}$ The practice of returning to shrines and temples to give thanks for favors, blessings and benefits received is not just emphasized as a moral injunction by Buddhist and Shinto priests and institutions alike (perhaps not surprisingly, since this involves return visits and donations to the insti- 
tutions); it is also a major theme within Japanese shrine and temple visiting, and within popular religious practice. Indeed, studies of shrine-visiting activity, based on Ishikiri shrine in eastern Osaka, show that a large number of such visitors, especially long-term regular visitors, are motivated by the wish to give thanks and repay gratitude to the deity for benefits received in the past. ${ }^{45}$

Seeking benefits in this world thus is a central aspect of all Japanese religion, which expresses commonly held views of the world and reflects ethical values and shared assumptions; it is thus part of civil religion, one that perhaps all Japanese of whatever personal religious faith would share, carried out in virtually all religious traditions and movements active in Japan. As a final comment on this point, and as an illustration that I consider shows how intrinsic and hence non-controversial this whole process is, I would like to mention a visit $I$ made to a famous Buddhist temple in the area adjacent to Tokyo in January 1993. This particular temple is extremely popular as a center where all manner of benefits may be sought, attracting vast hordes of visitors throughout the year, particularly at New Year when the numbers run into the millions. It has become especially well-known in recent years as a place to petition for traffic safety, and it has built a special sub-temple where services for road traffic safety are performed. The sub-temple has a large parking area in front where the drivers taking part in the service park their vehicles; after they have received their good luck talismans in the temple, the drivers return to their cars, which are then blessed by the priests.

One of its priests showed me a book outlining the temple's recent history, and what caught my eye was a photograph of a traffic safety service held by the temple for the police department of the local prefecture. The photograph showed rows of police cars and motorbikes, flanked by a large number of policemen, all being blessed by the priests. Who, I asked, paid for the service and the talismans (which, as with all religious charms and the like in Japan require a donation to the temple)? The priest responded that, as far as he could tell, the police department did; in his view this was perfectly natural since it was the department's men and vehicles who gained the spiritual protection provided. When I queried whether this might have infringed the constitution, in that it involved the use of public funds given to and for the benefit of a religious institution, the priest at first looked surprised; on reflection he felt that it probably did, but that no one had ever thought of that, and that no one had ever objected. 
After all, the police were doing something, i.e. vowing to drive safely and bring good order to the public highways, that would be approved of by all, and they were expressing concerns and wishes for their own safety as well as for the general public, again goals and values that the vast majority would understand and sympathize with.

I mention this story not to make a value judgment about a probable violation of the constitution (indeed, I cannot see any grounds for objecting to what the police had done) but to illustrate just how prevalent and commonly accepted the practice of praying for and seeking benefits is. Indeed, I would surmise that similar technical infringements of the constitution take place on a fairly regular basis throughout Japan; I myself have come across other cases, including instances where public institutions have had memorial services for deceased members done at temples. Here is an activity that is entirely central to the consciousness of the vast majority of Japanese, and closely aligned with their feelings of what is right and what should be done. If the police are to drive their automobiles for the sake of the general good, it would seem only reasonable that they should be given blessings for the purpose; it would, indeed, seem rather unreasonable for anyone to object on constitutional grounds to this.

We can see here a rather marked difference between this case and that of Yasukuni shrine, which has been suggested as a potential symbol at the heart of Japanese civil religion. Yasukuni is, as has been previously argued, highly contentious and more likely to provoke dissent and conflict than unity and a commonly shared sense of religious orientation. Conversely praying for benefits, with the underlying meanings it expresses, in the ways that the police force in question did, is not contentious. Rather, one would suggest, it would meet with general approval, testament to the fact that it is a commonly accepted force within Japanese culture. The action of a police department in using public funds in a prayer service to bless their patrol cars and motorbikes is thus an operative expression of a Japanese civil religion that virtually all Japanese can feel at home with. 


\section{Conclusions}

As this article has made clear, I am in agreement with those who consider that a civil religion exists in Japan today. It is not, however, one that is framed around contentious symbols that invite dissent. To that degree it is not primarily concerned with the state as a political entity, but with Japan as an emotional and cultural construct.

Although (unlike specific religions which have set doctrines and organizational structures) civil religion is to some degree unstructured, it can be said to incorporate three primary and interrelated areas in Japan. The first is concerned, on an emotional level, with images, with cultural identity and a sense of shared heritage. The Nihonron theories are an expression of this, as are the uses made of the images conjured up in the uses of the concept of the furusato. The second is centered on participation in various rituals and festivals that deal with and contextualize the life cycle and calendrical changes, and with expressions of commitment to units of social belonging such as family, community and nation. This component element within Japanese civil religion thus to some degree provides a channel through which the previously mentioned emotional images concerned with identity may be materialized. The third, vital, component is that manifested through the process of praying for benefits, which expresses ethical values concerned with the common good, and with the importance of seeking prosperity and happiness not just as personal but as social values, that legitimates economic development and personal success, and provides social and cultural values and goals that encourage a sense of pride in the community and nation at large.

All of these elements are things with which the very large majority can find empathy and in which they take part. As such Japanese civil religion is in fact a popular and practical religion, underpinned by emotional values concerned with Japanese identity, reinforced by practical actions. It constitutes a shared set of values and actions designed to produce and uphold a happy and prosperous life for the community at large as well as for the individuals within it, while providing them with a sense of belonging and pride in that community.

As a final comment, however, it should be pointed out that not everyone in Japan will necessarily find common cause with this civil religion. In particular those groups who are ethnically different from 
the Japanese (and contrary to the much-vaunted homogeneity of Japan there are relatively large ethnic minorities in Japan, notably the Koreans and Chinese) and have their own indigenous religious structures and practices, are not therefore liable to share in this civil religion. Equally, whilst much of what I have discussed as being part of civil religion has a centralizing impetus (in that it points to shared national identities, assumptions and practices) there are underlying affirmations also of regionalism and reassertions of local identity within them, as I have commented with regard to the celebration of festivals such as those at New Year. Nonetheless, I would suggest that there are enough common elements, shared at present by a large enough majority of Japanese, that incorporate matters of practical religious behavior and action, notions of shared identity, and ethical considerations about the nature of life and of society and community, to constitute a civil religion - which could also legitimately be called popular religion, since it is of the people, and is widely shared - operative in Japan today. This civil religion, unlike the American civil religion discussed by Bellah, whose symbols and images were utilized by politicians to create unity, is not coterminous with the state or directly connected to it. Indeed it may well be that its strength as a common religion of the Japanese lies in its not being closely associated with the state as such. This is not to say that it cannot be manipulated, or that attempts have not been made to utilize its images for political purposes; indeed, past examples have shown how such a process, if directed by the full force of a centralized state, could take place. Nonetheless, it is probably fair to say that, in the present age Japanese civil religion is separate from the realms of politics and the state, and that much of its strength derives from its avoidance of such areas of potential dispute.

What the future of Japanese civil religion is, is another matter, however. As this article has suggested, changing circumstances have had their effect on the developments of this civil religion which, in its present form, has developed in the postwar era after the separation of the religion-state axis that so powerfully shaped Japanese society, values and sense of identity in previous eras. How the continuing processes of change within society in the latter years of the century will affect this shared set of values and practices is a matter for future conjecture. Unlike the USA, where ethnic diversity has played a part in causing large areas of the population to reject what was essentially a white middle class-based civil religion of identity, Japan 
still retains (despite the minorities mentioned above and numerous internal tensions) enough of a commonly shared culture, customs, actions and attitudes, for the notion of an operative civil religion to have some meaning. Whether, however, this will in its turn be eroded or undermined by social changes, as has been the case in the USA, or whether civil religion itself will adapt and change, and in what ways, is a question of interest that will require further attention in the future.

Dr. Ian Reader is a member of the Department of Japanese Studies at the University of Stirling in Scotland. In August 1995 he will take up a position as Senior Research Fellow at the Nordic Institute of Asian Studies in Copenhagen.This article is a revised version of a lecture delivered at the University of Copenhagen, February, 1994.

\section{NOTES}

1 This is set out in Article 20 of the 1946 Constitution and reinforced by Article 89 which prohibits the expenditure of public funds for the benefit of religious institutions.

2 Robert N. Bellah, "Civil Religion in America," Daedalus, Vol. 96, No. 1 (1967), pp. 1-21

3 For discussions of these issues see Nishijima Takeo, Shinshuukyoo no kamigami (Tokyo: Koodansha, 1988) and Shimazono Susumu, Shin shinsurkyoo to shuukyoo buumu (Tokyo: Iwanami Booklets, 1992) as well as my own. comments in Ian Reader, Relig1ion in Contemporary Japan (Basingstoke: Macmillans, and Honolulu: University of Hawaii, 1991), all of which provide general overviews of these trends; while no major comprehensive study of the situation in the 1990s has yet been published, it would be fair to state that the trends identified by Nishijima and Shimazono remain accurate for the 1990s.

$4 \mathrm{H}$. Byron Earhart, Japanese Religion: Unity and Diversity (Belmont, Cal.: Wadsworth, 1982)
5 Reader, Religion in Contemporary Japan; and Ian Reader, "Shuukyoo ni okeru Nihon bunka no ichi" in Kokusai Nihon Bunka Kenkyuu Senta, ed., Sekai no naka no Nihon, Vol. 3 (Kyoto: Kokusai Nihon Bunka Kenkyu Senta, 1991) pp. 117-135.

6 Earhart, for example, draws attention to certain core themes in Japanese religious history and talks of the unity and diversity of Japanese religion, with a particular emphasis on the unifying themes within different religious traditions. One of the core and recurrent themes of Japanese religious history that Earhart mentions is the close association between religion and state; see Earhart, Japanese Religion: Unity and Diversity.

7 Bellah, "Civil Religion in America."

8 Ibid., p. 3.

9 Ibid., p. 11.

10 Ibid., p. 3.

11 Ibid., p. 8.

12 Ibid., p. 13.

13 Ibid., pp. 15-16.

14 Karel Dobbelaere, "Civil Religion and the Integration of Society: A Theoretical 
Ian Reader

Reflection and an Appraisal," Japanese Journal of Religious Studies, Vol. 13, No. 2-3 (1986), pp. 127-146.

15 Robert N. Bellah, The Broken Covenant: Civil Religion in Time of Trial (New York: The Seabury Press, 1975).

16 Dobbelaere, "Civil Religion and the Integration of Society," pp. 136-137.

17 K. Peter Takayama, "The Revitalization of Japanese Civil Religion" in Mark R. Mullins, Shimazono Susumu, and Paul L. Swanson, eds., Religion and Society in Modern Japan (Berkeley: Asian Humanities Press, 1993), pp. 105-120.

18 Ibid., p. 105.

19 I have discussed this elsewhere, e.g. Ian Reader, "Back to the Future: Images of Nostalgia and Renewal in a Japanese Religious Context," Japanese Journal of Religious Studies, Vol. 14, No. 4 (1987), pp. 287-303.

20 The significance of this term as an image and concept has been discussed both by myself, in Reader, "Back to the Future, $_{r}$ with particular reference to religious usages, and by Jennifer Robertson in more political terms in Jennifer Robertson, "Furusato Japan: the Culture and Politics of Nostalgia," Politics, Culture and Society, Vol. 1, No. 4 (1988), pp. 494-518. Robertson discusses how the image and concept of the furusato has been used by political groups, notably the Liberal Democratic Party (LDP), to boost their attempts to reassert their commitment to basic Japanese values.

21 Robertson, "Furusato Japan: the Culture and Politics of Nostalgia."

22 Reader, "Back to the Future," pp. 294298.

23 Winston Davis, Japanese Religion and Society: Paradigms of Social Change (Albany: SUNY Press, 1992).

24 Ibid., p. 253, Davis' italics.

$25 \mathrm{Ibid}$.

26 Ibid., p. 269.

27 Yanagawa Keiichi and Abe Yoshiya, "Some Observations on the Sociology of Religion in Japan," Japanese Journal of Religious Studies, Vol. 5, No. 1 (1978), pp. 5-27.
28 It is perhaps relevant here to note that Dobbelaere, not a specialist on Japanese religion although he spent some time in Japan, was a friend of Yanagawa, and wrote his essay as a contribution to a special issue of the Japanese Journal of Religious Studies in honor of Professor Yanagawa.

29 Dobbelaere, "Civil Religion and the Integration of Society," p. 137.

30 Ibid.

31 Ibid.

32 Ibid.

33 Although this event has been secularized, with the rituals conferring the attainment of majority taking place at civic centers nowadays, it was formerly a religious event held at shrines, and it is still common for young people on this day to also visit a shrine as well.

34 Dobbelaere, "Civil Religion and the Integration of Society," p. 140.

35 The uses made by business companies of Buddhist temple retreats as a means of instilling such values into their employees is well known, and is well described in, for example, Thomas Rohlen's article discussing one such retreat and the messages learned by bank employees at a Buddhist temples; see Thomas P. Rohlen, "Spiritual Education in a Japanese Bank," American Anthropologist, Vol. 75 (1973), pp. 1547-1562.

36 This point is clearly recognized by Akaike and Swyngedouw in their introduction to the volume in which Dobbelaere's article appears, in which they suggest his separation of Shinto and Buddhism into the categories of "conventional" religion and "operative" religion "might raise some eyebrows;" see Akaike Noriaki and Jan Swyngedouw, "Editor's Introduction," Japanese Journal of Religious Studies, Vol. 13, No. 2-3, pp. 119-125.

37 See, for example, my comments in Reader, Religion in Contemporary Japan, pp. 227-233.

38 See Robertson, "Furusato Japan: the Culture and Politics of Nostalgia," p. 494. 
39 Kurehayashi Shooji, Matsuri no koozoo (Tokyo: NHK Books, 1984), p. 11.

40 Inoue Nobutaka, et. al, "A Festival with Anonymous Kami: The Koobe Matsuri,"Japanese Journal of Religious Studies, Vol. 6, No. 1-2, pp. 163-185.

41 I have discussed the rituals associated with New Year, and their underlying meanings, in Ian Reader, "Japanese New Year: Transition, Festivity, and Religion," in Reiko Mochinaga Brandon and Barbara Stephan, eds., Spirit and Symbol: The Japanese New Year (Honolulu: Honolulu Academy of Arts, 1994), pp. 109-139.

42 Reader, Religion in Contemporary Japan, p. 54.

43 See, for example, Helen Hardacre, Kurozumikyo and the New Religions of Japan (Princeton: Princeton University Press, 1986).

44 The Shushoogi is in effect a late nineteenth century text drawn from various writings by the sect founder Doogen; it was heavily edited by Soto leaders in order to provide an appropriate teaching for the modern day for Soto laity and priests alike, and is considered a core text for the modern sect, outlining many of jits aims and values.

45 Shuukyoo shakaigaku no kai, eds., Ikoma no kamigami: gendai toshi no minzoku shuukyoo (Osaka: Soogensha, 1985), p. 130. 